This is an author produced version of a paper published in Critical Policy Studies. This paper has been peer-reviewed but does not include the final publisher proof-corrections or journal pagination.

Citation for the published paper:

Lundberg, Anna; Strange, Michael. (2017). Struggles over human rights in local government : the case of access to education for undocumented youth in Malmö, Sweden. Critical Policy Studies, vol. 11, issue 2, p. null

URL: https://doi.org/10.1080/19460171.2016.1142456

Publisher: Taylor \& Francis

This document has been downloaded from MUEP (https://muep.mah.se) / DIVA (https://mau.diva-portal.org). 


\section{Struggles over Human Rights in Local Government - the case of access to education for undocumented youth in Malmö, Sweden}

By Anna Lundberg and Michael Strange (a later version of this article has been published in Critical policy studies:

http://www.tandfonline.com/doi/full/10.1080/19460171.2016.1142456)

\section{Introduction}

Negotiation over human rights often appears as the preserve of international meetings, with nation-states as the central actors. However, as argued here, the decontestatory process through which human rights are made real - that is, where they impact human lives - needs to be better understood as consisting of everyday policy decisions taken at the local level. To help elucidate the everyday local policy context through which human rights is often realised, this article focuses upon a particular case - negotiations over the human right to education for undocumented migrant children in Malmö, Sweden.

In recent years this topic has sparked a highly politicised debate in Sweden in general and in the city of Malmö particularly. There have been incidents in Malmö where students were excluded from the regular process governing access to school, and some schools denied access to the special support otherwise normally provided, with reference to the students' legal status as undocumented. The controversy sparked a debate in the local media, academia, and among refugee rights organisations over the right to education as well as the impending risk of deportation faced by persons attending school in Malmö while present in Sweden without legal authorisation (Jernberg, Karlsson and Martinsson 2013; Nilsson 2011; Sveriges Radio P1 2013).

As a case of negotiation over human rights at the local level, it serves to identify several key reasons why the local level matters. First, as the article will elaborate further on, the local level is where we can understand rights-claims by rights-holders themselves or on their behalf. A second reason are the various practical considerations taken when policy is implemented. Third, it is often at the local level of implementation that conflicts of interest over human rights become most visible. Fourth, the local level is particularly vulnerable to a diverse set of regulatory levels due to its relative subordination.

Overall, the article argues that there is a need to re-examine human rights as an idea beyond agreements formed at the international and national levels that are implemented locally (cf. Risse and Sikkink 1998). They are in fact also invented, and reinvented, in local contexts and in this setting, as Irene Hadiprayitno (2014) points out, the relationship between global, national and local laws pertaining to human rights is arguably fluid. Our case shows that manifestations of public policy symbolise the commodification of public services, the fluid nature of policy, the uneven course of reform and the challenges of policy implementation. With regards to the perspective of persons directly affected by policy changes - we call them rights-holders - their inclusion in policy making is usually dealt with as a technical problem and not as a question of mobilising distinctive knowledge and experiences (Orsini and Smith 2010). In other words, experiences of those who are affected by policy are seldom taken into considerations when the policies are established. The data presented in this paper contributes to a broader understanding of the local level of human rights, through allowing empirical mapping of the complex processes through which this local level negotiation of human rights takes place. 
The negotiation over human rights has particular salience when those rights concern the lives of irregular child migrants. Hostile political environments are a fact for stigmatized populations such as vulnerable migrants (Bhabha 2009; White et al. 2011). Simultaneously there is a growing recognition of the need to safeguard human rights also for vulnerable migrant groups that are staying irregularly (Betts 2010). In recent years there has been a renaissance of 'immigrant protests', rights claiming by irregular migrants and pro-migrant activists (Isin 2008; McNevin 2006; Nyers 2003, 2008; Rygiel 2010). In studies of such movements, the cities, in contrast to the state level, have proved to provide a space for challenges to these processes of illegalisation and a space for regularisation from below (McDonald 2012). These disruptions at the city level do not necessarily change the status quo but, as Anne McNevin (2011) explains, engagement by and on behalf of undocumented migrants constitute a protest over how states categorise migrants as objects of governance. Our contribution is to draw a picture over how this plays out locally in relation to irregular migration. Through enhancement of visibility, and by changing perspectives so that illegality no longer equates with illegitimacy, the parameters of the politics of non-citizens is transformed from below (McNevin 2011).

Beyond these broader developments and understandings, the present study focuses on competing discourses over the legitimate criteria for determining the correct interpretation of human rights. Our research is thereby a contribution to a growing body of literature on the negotiated character of human rights policy (Risse 2013, Carter 2011, Merry 2006). Our single case and interviews give an insight into what level is referred to, and what matters when human rights are invented.

The case of the human right to education for migrant children in the city of Malmö is particularly salient given that it is one of the centres of immigration within northern Europe. Estimates of the number of undocumented migrants, children and adults, in Sweden vary between 10,000 to 50,000 people (Socialstyrelsen 2011). Malmö, being the city in Sweden closest to the continent situated at the foot of the bridge from Denmark, receives almost half of all asylum seeking youth arriving to Sweden as unaccompanied mostly they are boys from Afghanistan and Somalia between 15-17 years old (Malmsten 2012 , p. 20). By the end of 2013 there were approximately 265 children and youth searched for deportation in Malmö, these were all persons whose asylum applications had been rejected. ${ }^{\mathrm{T}}$

The article is structured as follows. First, it reviews how existing research has tried to understand the human rights of undocumented migrants in general and undocumented children in particular. Human rights are grounded within a complex process of political negotiation subject to multiple contestations outside of which they lack meaning or substance. For the rights-bearers, in our case migrant children lacking a residence permit in the state, human rights often rely upon negotiation processes at the local city-, or in some cases the individual, level that otherwise tend to be overlooked by the existing literature. Second, the article maps the broader national debate to provide readers with an understanding of the overall tension that characterizes the issue of undocumented migrants' human rights, between children's rights on one hand and the management of migration on the other. Third, the case of access to education for undocumented children in Malmö Sweden is presented, including our methodological approach which is inspired by critical contextual empiricism (Longino 2002). The latter views science as created in the interaction between researchers and the world around 
them and notes the importance of emphasizing marginalised groups' experiences, to reach insights that are impossible for the privileged to understand. Fourth and final, the significance for a society to develop a persistent infrastructure for access to human rights in society at large is also discussed.

\section{The Multilevel Creative Constitution of Human Rights}

Inspired by Hannah Arendt (1951 ch. 9, also see Bhabha 2009), and other scholars working with her, we understand human rights as a political negotiation, setting out from the position of rights-holders themselves (Ingram 2008; Squire and Darling 2013). The invention of human rights is a creative, democratic process, and as James Ingram states, challenging 'particular exclusions and inequalities in the name of the open-ended principle of equal freedom, which acquires its particular contours only through this contestation' (2008: 412).

Arendt pointed to the link between having membership in a political community on the one hand and being able to claim protection of rights on the other hand. Humans are, in Arendt's phrase, not born equal but may become so in a political community, and citizenship constitutes the basis of such membership. Therefore one basic human right is the most important, the right to have rights (Arendt 1951: ch 9). A person may be involved in developing a political community where access to rights is safeguarded, but without membership a person's agency becomes dependent on others acting together with them, or on behalf of them.

Debating Arendt's work in the field of human rights, Benhabib (2007) focuses on political membership and what she describes as the evolution of cosmopolitan norms. These originate through treaty-like obligations, such as the UN Charter (1945), the Universal Declaration of Human Rights (1948) and, when children are concerned, The Convention on the Rights of the Child (1989, hereinafter CRC). What characterizes these agreements, Benhabib argues, is that they bind states and their representatives, sometimes against their own will. As a consequence the principal category through which membership has been regulated in the modern world, namely national citizenship, has been successively disaggregated. Nationality and legal status are uncoupled in that increasing numbers of individuals reside in countries where they are not nationals. Furthermore, residency is contemporarily accompanied today by entitlement to extensive social rights (Benhabib 2007: 49). It is therefore reasonable to assume that an undeniable - although limited and conditioned - space to have rights exists today, even for non-citizens. One indicator of this is the growing recognition of a significant human rights-gap between rhetoric and reality - at both the normative and especially the operational level - with respect to a number of groups of vulnerable migrants (Betts 2010; Ruiz-Casares et al. 2010). This gap between formal rights and rights-in-practice is especially experienced by persons who are undocumented since they are not allowed to exist in the sphere of individual rights-bearers making claims in relation to the state.

With few exceptions (see Schech 2013) scholars exploring the institutionalisation or implementation of human rights norms tend to turn to the state as the unit of analysis. Since the dawn of the new millennium it has become more and more apparent how human rights are being deployed to justify wars and domination (Douzinas 2007). Scholars have shown that human rights are not always deployed to advance 
emancipatory projects (e.g., Perugini and Rabie 2012), and they are often integral to apparatuses of governmentality (Brown 2004; Foucault et al. 1991) aimed at governing the conduct of individuals and groups. While qualitative studies suggest that human rights can have a substantial impact on social change (Hafner-Burton and Ron, 2009), still, as pointed out by Gordon and Berkovitch (forthcoming 2014), they tend to disregard divergences of implementation within a country.

\section{Human Rights for Undocumented Persons}

How have rights for undocumented persons in general and undocumented children in particular been explored in research? One central dimension when negotiating rights for undocumented persons is that they are physically present but socially and legally absent in a society. They personify what scholars discuss in terms of being unable to engage the states' 'welfare jurisdiction' without also 'triggering its immigration jurisdiction' (Noll 2010, p. 248). Hence, a person staying unauthorised may be physically present, sometimes for several years, but socially and legally absent through the denial of rights or impediments to their enjoyment (Kesby 2012, p. 110). This absence is one felt not only by the undocumented migrant, but is experienced by the host society as an internal 'void'. To be undocumented means to be excluded from the sphere of persons to which the state is accountable. To be undocumented is to have limited access to rights and, as Monica Krause (2008) has noted, this is the common denominator of undocumented migrants' political existence within state territories. Simultaneously, while undocumented migrants are deprived of legal status they also embody the contradictions of the arrangements that exclude them. They represent an emptiness in which society fails to perform itself within part of the territory that is the legally-defined basis of its existence. As a consequence, their public appearance is explosive and potentially liberating for society (Krause 2008).

This conclusion is reinforced by the fact that migratory movements have the potential to 'throw into question the possibility of identifying an inside and outside' and as a result they then become the objects of politics of regulation even though excluded (Mezzadra and Neilson 2003, para. 7-8). In sum, children in an undocumented situation are highly politicised. Their presence as undocumented persons creates expectations and pressure for inclusion. This is done either by undocumented themselves or on their behalf (Rygiel 2011; Strange and Lundberg 2014).

\section{Education as a human right}

An undocumented refugee child's rights in this context are particularly controversial areas due to their triply subordinated position: as child, as forced migrant and as unauthorised. Primarily, children need protection in a way that does not apply to adults, placing greater demands on the rights-provider. Largely speaking, children rely more on human rights than adults do. In the private sphere at least young children are dependent upon adults/care-givers and, in relation to the state, children and youth are dependent upon the existence of institutional conditions for services such as education. Education is a prerequisite for children's long-term capability of claiming other human rights. Furthermore children do not have voting rights and therefore their interests tend to be overshadowed by other groups' interests. The children are also in a vulnerable position, given that they have no long history in Sweden, which means that they do not have the same sense of consistency as other children who live there. Undocumented children are 
thus categorised as heavily subordinated and human rights are thought to compensate for these demotions.

One of the most obvious characteristics of children's rights, manifested in the CRC, which has had an impact in the world beyond other human rights documents, is the political recognition of the fact that children are subordinate in society, in politics, and in institutions such as the family. In scholarly work on the realisation of children's rights it is almost inconceivable to not consider the CRC as the bearer of the children's rights debate (Reynaert et al. 2009). A starting point in the treaty is that 'childhood is entitled to special care and assistance' (preamble CRC). Advocates for better access to education for undocumented child migrants likewise refer to this international treaty in which education for children is recognized as a fundamental human right. Article 28 in the CRC states free and compulsory education to all and that measures should be undertaken to ensure that school discipline is administered in a manner consistent with the child's human dignity. In article 29 of the Convention it is further stated that education of the child shall be directed to the development of respect for human rights and fundamental freedoms, and for the principles enshrined in the Charter of the United Nations. Thus, there is a link between access to and content of education that might be relevant in schools receiving children with different legal statuses. Embedded in the right to education is the right to be treated with respect in educational settings. Wouter Vandenhole et al. (2011) in a study of the Belgian context, shows with regard to undocumented children that real-life limitations to school access (both individual and institutional), as well as psycho-social and institutional impediments during the schooling process seriously limit equal schooling and life opportunities. A key factor, conclude Vandenhole et al. (2011), in understanding the tension between the legal recognition of the human right to education and daily realities for undocumented migrant children in school, is the outright contradiction between the approaches towards education on the one hand, and to migration more generally on the other hand. Furthermore, the right to education for children who reside unauthorised concerns also their peers, children who have residence permits. The provision of education, we argue, is an explicit means by which society builds the social glue through which its members are linked, and in this sense it provides an ideal example by which to understand the role of human rights negotiations as fundamental to these relations. The relationship between the situation of undocumented children having human rights as children and therefore access to education, provided in the public sphere, tell us something about society as a whole. Their situation becomes a litmus paper for equality in society at large.

\section{The Radical Necessity of Rights for Undocumented Child Migrants}

School is both a 'border' by which undocumented child migrants are excluded or included within society, but also where society can make itself felt by the individual child migrant. Child migrants' experiences of a society are directly related to their experiences from school. This is not a superficial matter but comes down to the way in which society is made visible as a physical entity with material effects, which go beyond the 'idea' of its existence. The ability of undocumented child migrants to attend school within host countries also impacts their everyday lives, as demonstrated in studies conducted in Sweden (Lundberg and Söderman forthcoming). Getting access to the everyday routines provided by school could be a question of survival in certain situations. School also means social contacts with peers and adults. In light of these 
rights to and advocacy for education, undocumented children's rights should be a matter of implementation in terms of reaching out to the rights-holders. An aggravating circumstance, however, which is not about the allocation of resources, is their status as unauthorised residents on state territory.

While unequal distribution of human rights across a country's population has not been researched to any great extent (Gordon and Berkovitch forthcoming 2014: 3), and nor has local human rights negotiations in the field of irregularity and migration (for an investigation on children's rights in the Swedish asylum process, see Lundberg 2011), the theoretical dichotomy between universality and particularity has been discussed widely (see f.ex. Nussbaum 2003; Benhabib 2008; Charvet 1998, Adami 2012). Rebecca Adami (2012) in this context puts forth a thesis that human rights discourse can work as a cosmopolitan space, in which particular value systems meet in processes characterized by conflict and cohesion. She concludes that understandings of human rights originate from our locality and through our particular value systems, with which we identify. Local values narrated within a human rights discourse 'interconnects us to millions of others, rooted in their particular value system' (Adami 2012, p. 34). Drawing on Langlois (2001), Adami takes the understanding of 'universality' beyond theoretical struggles of human rights legitimacy, towards reconciling 'universal' and 'particular' values in the cosmopolitan space that human rights offer as discourse. This is done by taking the universal through the particular, and by acknowledging the tensions that may arise (Adami 2012).

Despite, or perhaps because of, its ideological hegemony (Donnelly 2013, p. 152), human rights at the local level have proved to be a suitable mechanism to dissolve unjust dominations. In her socio-legal approach to human rights negotiations, Hadiprayitno (2014) draws on human rights as a socially constructed concept that is invented through continuous and circular practices of negotiations. The practice in this regard implies an understanding of human rights as the means through which the idea of rights becomes discursive. Conducting a case study of development projects in Merauke, a region located in the most Southern tip of the island of Papua, Indonesia Hadiprayitno describes the invocation of human rights ideals in negotiation processes. The concept of human rights in the study presented a formation of new hierarchies and contexts in which struggles for negotiating and claiming rights could play out. Furthermore it provided a basis for breaking away from spatial metaphors that link law to the territorial State. The presumed aims of human rights practices, states Hadiprayitno, are to clarify the notions of rights and obligations as well as to reconfigure the relationship between state and individuals:

To assert human rights, and its cosmopolitan values, is to make a fundamentally political claim; that one is entitled to equal moral respect and social status, support, protection necessary from the duty bearers (Hadiprayitno 2014).

Gordon and Berkovitch (forthcoming 2015) introduce the term 'differentiated decoupling' to capture variances of implementation across different social groups within a given society, and apply perspectives and methods from the sociology of inequality to explain specific patterns of implementation. The concept of decoupling is used to problematize the widespread phenomenon of states that sign conventions but do not comply by these legal treaties. Through the notion of 'differentiated decoupling', whereby human rights standards may be tightly linked to practices vis-à-vis some 
groups within a given society but decoupled with respect to other groups, the unequal distribution of human rights in domestic settings may be revealed. Arguing that the implementation of human rights norms needs to be re-thought and re-operationalized, Gordon and Berkovitch present two case studies (the right to vote in the US and the right to work of people with disability in Ireland) pointing to the importance of examining different social groups within a state rather than limit scrutiny to the state level. Studies of access to rights for women and children, they argue, are a good starting point for understanding differentiated decoupling (see Hill 2010). But if one wants to capture the different degrees of decoupling it is also important to examine the intersectional axes of oppression, or how the implementation of human rights norms can actually deepen stratification.

Through a qualitative in-depth case study in the field of undocumented children residing in the city of Malmö Sweden we wish to contribute to current research on policy development in the field of children's rights, pointing out possible areas of concern as regards how children's rights may be understood in local contexts (c.f. Quennerstedt 2013). Negotiations, rights claiming, wherever it takes place, we see as a demonstration of how rights might occur. As Ingram puts it, "The language of human rights is not only that of the Universal Declaration; it is that in which they are claimed and won' (Ingram 2008, p. 413).

\section{Policy Debates in the Swedish human rights}

The national debate on human rights for undocumented migrant children usually departs from human rights obligations and sometimes also from the Swedish Constitution. The latter states that 'foreigners' are equated with Swedish nationals if nothing else is stated in national legislation (see Press act [Tryckfrihetsförordningen] ch. 14, para. 5). Advocates for granting access to education for undocumented migrants now and then refer to international treaties granting education for all children as a basic human right. Being a State Party to international treaties, Sweden, as pointed to in the debate, has also been subject to criticism from the UN Children's Rights Committee due to the fact that children in an undocumented situation lack the same entitlement to school as children granted permanent residence. Several times the Swedish government has been recommended to take immediate steps to ensure that national laws guarantee access to school for children living clandestinely (See f.ex. Committee on Economic, Social and Cultural Rights; comment on the Swedish government's report to the Committee 2008, para. 27; CRC-committee 2009, para. 55).

Following this national and international criticism, the Swedish government has made legislative changes so that undocumented children from summer 2013 should have a right to school. These changes reflect a wider discourse in which mainstream political parties in Sweden have tried to distance themselves from the exclusionary rhetoric of the xenophobic political party Sweden Democrats (cf. Oberoi 2013, p. 181f.). However, the rights are often conditioned, for example the new legislation on right to school opposes the existence of sanctuaries in Swedish territory. Formal sanctuaries imply that the Police is prohibited from searching for people whom should be expelled from Sweden. Since, from the youth's perspective, a major challenge when engaging welfareservices is that the deportation machinery is triggered, their perspective wasn't considered. The legislation allows the police to continue searching for undocumented persons all over Swedish territory with no exception given to school grounds as a 
special environment. The fact that the tension, between migration control on the one hand and students' expectation of safe and secure school on the other hand was not dissolved in the preparations of the legislations has been criticised (Nilsson 2011).

\section{Methodological approach and the Malmö context}

This article is based on fieldwork conducted during $2012^{1}$ within the framework of a larger research project about undocumented children's rights-claims. The study adopts an action-oriented approach meaning that activities were aiming at both understanding and at facilitating activities intended to improve access to formalised rights for undocumented youth in Malmö. This included focusing on healthcare, school, and access to support from the social services (Lundberg and Söderman forthcoming 2015). In the process of the present article we limit the analysis to a discussion around negotiations on inclusion and exclusion in access to school as a human right. The material that forms the basis of our enquiry is firstly the fieldwork in Malmö including a meeting held in the city to safe-guard the right to education, and interviews conducted with teachers, other school staff and one of the city attorneys. Six interviews we conducted over phone or in person. ${ }^{2}$ With the aim to understand the right to education as a health-determinant, i.e. an important dimension of a healthy life, we wanted to explore the meaning of rights, and access to rights according to service providers in the city of Malmö. Besides the interviews for this article we conducted 20 interviews with nurses, doctors and servants in the social services. The analysis below is based on, besides interviews, activist fieldwork in Malmö as well as the broader policy debate in Sweden. Our interviews and the case presented provide an example by which to study the negotiation of human rights as they are experienced at the local level. How are universal human rights enshrined in the negotiations? How does different actors relate to human rights as experiences of undocumented children residing in the city? And, what are the implications for the rights-bearers themselves?

At the time of our fieldwork the debate around the right to school in Malmö for undocumented children had been going on for several years. ${ }^{3}$ A cross-party agreement had been adopted in 2012 stipulating, 'undocumented children should be offered schooling' (authors' translation, platform until 2010-2014). The decision had also been allocated in the municipality's budget. Despite these measures, there was (and is) still a situation of limited access to school. One reason for this is the fact, as already noted, that

\footnotetext{
${ }^{1}$ The project was conducted by AUTHOR 1 in collaboration with [NN], and funded by Malmö Institute for Studies of Migration, Diversity and Welfare and "Challenges of Migration” a research program that connects issues of health and migration involving the City of Malmö, Malmö University and Skåne Region Council.

21. Principal A in our article (also attending the meeting)

2. Councelor at a Malmö-gymnasium, wanted to be anonymous to protect a boy in clandestinity.

3. Development secretary at research and development in Malmö, focus education (see http://www.malmo.se/Kommun--politik/Sa-arbetar-vi-med.../Forskola-och-utbildning/Skolutveckling-Forskning/FoU-Malmo-utbildning.html)

4. Co-ordinator for language introduction in Malmö; worked for $5 \mathrm{y}$ with this. I believe she was also at the meeting.

5. Teacher working especially with children who has Swedish as second language. Working with older children today compared to before.

6. One of the city attorneys.

${ }^{3}$ In Sweden municipalities are responsible for the implementation of school activities and they have freedom to determine how schools should be organized for the national objectives to be achieved. The municipalities are also responsible for the schools, the resources and the necessary conditions for an equivalent school.
} 
no sanctuaries exist in Sweden. An irregular child can never escape the threat of deportation, and the pressure on the authorities to expand the search for undocumented persons keeps rising. In Sweden, the Police have gradually increased their ambitions spurred by politicians. Since 2007 the numbers of internal controls of foreigners have increased from ten thousand checks per year to 48,000 checks in 2012 (Stark 2014). The background is the Schengen agreement, which Sweden joined in 1999, along which the police had successively advanced its positions to streamline the internal control of foreigners. In 2011 the National Police adopted new guidelines on the matter stating that officers in their everyday work could take every opportunity to carry out checks, for example of the driver and any passengers (National police board [Rikspolisstyrelsen] 2011). 'A foreigner's behaviour' could be reason to believe that $s /$ he had no right to be in Sweden. Furthermore, the operations should be an integral part of all police work. A year before that the Minister for Justice Beatrice Ask stated that the police should 'significantly upturn the number of executed decisions' (Ask 2010). In the regulatory guidelines from the government to the authorities for 2014 it is stated as regards the police that the enforcement work should be more effective to further raise the number of deported persons (Government 2014 [Regleringsbrevet] esv.se).

Police enforcement efforts are thus enacted potentially everywhere at anytime. In the city of Malmö it was intensified in the beginning of 2012 through a new initiative; the police REVA project (legally secure and efficient enforcement work). ${ }^{4}$ More deportations at first came about of persons lacking residence permits in Sweden. However, the surveillance and security checks proved to have far-reaching impacts beyond undocumented migrants (Stark 2012) and heavy protests followed. REVA also led to a loss of legitimacy for state and local authorities, the objective of surveillance compromising their role as providers of essential public goods. Concern was voiced by several figures of authority, including a Malmo city councillor, Katrin Stjernfeldt Jammeh, who stated in a radio-interview at the time:

If children in Malmö don't dare to go to school or seek medical care because they are afraid the police will take them, we don't reach the city's goal that all children have access to school (Jammeh in Sveriges Radio P1, $6^{\text {th }}$ April 2013, authors' translation).

Outside of the national debate on undocumented persons Malmö also experienced a tragedy between December 2009 and October 2010 - the so-called 'Malmö shootings' where a string of shootings took place by one individual, targeting people who appeared 'non-Swedish' (Habel 2012). These attacks, one of which was fatal, caused deep concern in the city, where a large part, 31\%, of the population was born outside Sweden (The City Office [Stadskontoret], 2013). The attacks themselves, but also the increased police activity that followed, led to some undocumented youth refraining from going out at all.

To conclude there has been a national development for several years in Malmö and Sweden, pulling in contradictory directions. Nationally there has been inclusion of undocumented persons in welfare services. We saw this through the legislator's answer

\footnotetext{
${ }^{4}$ When REVA started in Malmö a controversy emerged within Swedish political circles and the media on the everyday dangers experienced by undocumented migrant children living within Swedish society (Stark 2012; Lundberg, 2013). In particular, these dangers included the risk undocumented migrant children faced of deportation through attempting to access their right to education by attending school. Despite national legislative changes intended to enshrine the right to school for all present in Sweden, in practice this was undermined.
} 
to the critique from the UN Children's rights committee and also in the cross-party Malmö-agreement on schooling. On the other hand, the Police have been instructed to raise the number of deportations of persons lacking a residence permit. Broader developments to do with increases in the number of refugees globally as well as persons migrating via irregular channels, and the growth in warzones preventing repatriation have made the Police's REVA-project inefficient. It is reasonable to say that the meaning of human rights for undocumented children in the context explored is fluid and unsolidified. Clearly, as Teresa Chataway concludes, 'Balancing border control with international and European fundamental human rights and commitments is a key complexity' (Chataway 2010, p. 377). Subsequently the rights may be used to exclude as well as to include undocumented children, as shown in the Malmö case. While some parties emphasise predictability and coherence as overarching aims, others put forward equal treatment, or access to spaces where rights are provided as most important.

Policy outcomes of the human right to education - the example of Malmö: a struggle between legalistic and experiential discourses

In the interviews conducted by one of the authors with personnel in the city of Malmö, recent policy actions for undocumented children in relation to access to education were additionally investigated. Analysing the interview answers, we found competing discourses on what is the correct way to invent human rights. What become apparent are two distinct discourses, here described as 'legalistic' and 'experiential', and they refer to what criteria actors use when legitimating their interpretation of human rights. A legalistic discourse is apparent whenever an actor justifies their interpretation of human rights based upon rules and regulations, varying according to the level at which they are formally authorised. In contrast, an experiential discourse refers to those incidents where actors evoke everyday accounts of human life to support their interpretation of human rights. The distinction relates back to the discussion developed earlier in the literature review, where human rights can be understood either formalistically, i.e. as a top-down formal process, or as a more radical bottom-up process

\section{A legalistic discourse}

One of the city attorneys declared that while the legislation on the national level, through ordinances, provide an opening for municipalities to offer schooling, there is no formal right to school in the municipalities:

... they [undocumented children] ... are not covered by all school procedures. There is a difference compared to other children in Malmö. But there is a possibility [to allow access for undocumented children; our emphasis] according to regulations (Interview City attorney, our emphasis).

In this understanding the right to education is determined entirely by reference to national regulations. Conversely those critical of this position can also make use of a legalistic approach. For example one of the school principals, Principal A, referred to the local level of regulations - the cross party agreement in Malmö on children's right to be offered school - as stating that no matter their legal status: 'the platform clearly says that there is a right to school' (Principal A).

Of the same opinion was the representative of the city's Department for Research and Development in the field of education. With reference to international law she stated: 
... actually there are no barriers [for access to school] - the Children's Rights Convention applies, all children have the right to education. But the formal barriers emerge because it can be interpreted in different ways, this is due to lacking a clear legal framework. In Malmö, there are no special regulations. No local regulation exists stating one should accept undocumented children ... they are not obliged to come to school, in that sense there is a difference. (Interview with representative of Malmö's Research and Development Department, our emphasis).

Both interviews here point to the fact that there are no barriers, formally, to school. Interestingly, whilst the actors interviewed express divergent views on the right of undocumented child migrants to the city's schools, all supported their arguments based upon a legalistic discourse. It should also be noted that each actor refers to a different level of regulations - respectively: the national, the local, and the international. In addition, the last interviewee indicates that legal ambiguity at the national and local level creates a problem for city officials and school administrators in deciding whether to provide access to school for undocumented child migrants.

\section{An experiential discourse}

Actors sometimes make use of both a legalistic and experiential discourse. For example, Principal A also makes direct reference to the experiences of undocumented child migrants to support interpreting human rights so as to ensure their access to school. Working in a school in Malmö attended by many unaccompanied refugee children, Principal A highlights arbitrariness as a hindrance for access. There is a wide discretion, he states, and this also affects the youth:

They are well aware that they are at the school because we think it is OK, not that they have the right to be there - already this makes them into second class students.

Aware of the sub-ordination, and the youth's experience of going to school because of mercy, makes it important for Principal A to focus on experienced access instead of negotiating formal barriers to school or technicalities such as registration on class lists. The coordinator for language education in Malmö confirmed the problem of uncertainty and also reflected upon what she describes as a strategy of silence throughout the system, in providing for access to education:

This depends on each individual school... It's pretty tight-lipped about these students - they are not on the lists, it's not that all colleagues know that we now have two boys in the class ... (coordinator for language education).

One way to understand the silence noted in the quotation is that it is a strategy providing a basis for equality before municipal institutions in the sense that undocumented children are present in school without anyone knowing. Here the interpretation of human rights clearly is not based on a legalistic discourse, seeing that the law is treated as an obstacle rather than protecting the right to education. The coordinator, when interviewed, also points to the dilemma around whether personnel should put undocumented persons' actual names on class lists:

A...problem [when in school] is whether or not the youth should be on the class list, which is required to be able to get grades [but might constitute an obstacle if the Police requests the lists] (Coordinator for Language Education).

Another challenge for school personnel in their everyday work brought up in our interviews regards the potential presence of police. 'I know that when police carried out 
searches within the city, we had a lower school attendance - that was obvious' (Principal A). Again, the legalistic discourse is seen here as insufficient to provide the criteria necessary for ensuring the right to education, since the national law is facilitating police activity undermining access to school. Instead, Principal A uses the security fears of the children concerned to justify his own interpretation of human rights that leads him to work beyond the narrow remit of the law to ensure access to education.

In the interview, Principal A makes frequent references to the self-perception of undocumented child migrants as a guiding principal by which to understand what is necessary in approaching the right to education:

The school system is structured for students to require, take place, and express their needs. If you have the feeling that one gets this because of someone else's benevolence - then it's difficult to express your requests. 'They've already given me school lunch, then I will not come and complain, too' (Principal A).

The right to education here is seen as depending not upon the law, but the everyday experiences of the children attending school. In particular, it is not just their attendance, but also how they perceive their position within the school environment, that is valued by Principal A. In the above analysis, the actors that rely most upon a legalistic discourse are those that are most closely tied to the administrative system - that is, the Malmö city attorney. This is perhaps not surprising, given their position. A lawyer working within the local governmental apparatus would be expected to refer most to a legalistic discourse. However, seeing how actors make use of a legalistic or experiential discourse helps aid analysis of the negotiated positions involved in interpreting human rights - in this case, the right to education - within the local context. The local context is particularly interesting here given that it is where implementation problems become most visible. It is not that there is a difference between human rights as formally stated and their implementation, but rather how actors make use of the discourses of either legalism or experience (read 'practice') in justifying their own interpretation of human rights. The city attorney does not deny the right to education, from her perspective, seeing its interpretation as determined by rules and regulations - a legalistic discourse. Where this is contested, other actors initially make use of a counter legalistic discourse via referring to alternate regulatory levels. Yet, where their critique becomes strongest is where they abandon the legalistic discourse to argue that human rights should be interpreted via an experiential discourse - that is here, where the everyday lives of undocumented child migrants are treated as evidence.

\section{Negotiating the human right to education - the example of a single meeting in Malmö}

Our fieldwork activity involved helping to prepare a meeting for discussions around the matter of education in May 2012, initiated by the refugee rights organisation the Asylum Group in Malmö. The participatory observations made by one of the authors provide a particularly useful opportunity through which to see the two divergent discourses identified above - experiential and legalistic - structuring negotiations over the human right to education in practice. That is because in addition to activists from the group, those present at the meeting were: officials including the city council's director of education; one of the city's attorneys; principals from the schools affected; as well as a psychologist working with refugees; and, contact persons for undocumented migrant youth living within Malmö. One of the authors to this paper took part as an expert in children's rights. The actors present deviated according to whether they justified their 
own interpretation of the human right to education according to either a legalistic or experiential discourse.

The meeting was organised in response to several incidents involving the city's schools, where students who were undocumented migrants had been excluded from the regular routines that applied in firstly getting a place in the school, and secondly in situations where students got into troublesome situations. First, undocumented migrants had experienced difficulty in accessing school due to an administrative obstacle, where children lacking residence permits were placed in a separate queue prolonging their wait for a school place. Second, undocumented migrants were denied access to the procedures otherwise normally provided to help students in difficulties, such as: low grades and under-performance; absenteism; conflicts within the school premises; or, exceeding the standard period of attendance. According to the routines for students in these difficult situations, a so-called 'student conference' is regularly arranged where teachers participate as well as school health personnel and special education teachers. The goal of such conferences is to establish an appropriate action plan and to ensure a safe and secure school environment for affected students. However, within Malmö, undocumented youth of school age had experienced that they were denied access to these remedial processes.

In the meeting in Spring 2012 one central discussion regarded how all children in the city of Malmö should be ensured a safe and secure school attendance, another purpose was to enable youth slightly over 18 to attend school. Just as is the case with Swedish students, irregular migrant youth should, the initiators argued, have access to school until the age of 19 as it had happened that youth were excluded from school when turning 18. A problem for some youth living as undocumented was that as soon as they turned 18, they, unlike Swedish students, lost their place in high school and needed to instead take part in the local authority's adult education.

\section{Equal access to education - a matter of legality, or experience}

There were different views among the participants in the meeting on how to deal with the question of equality within the educational system, with actors justifying their position according to either a discourse of legality or the experience of undocumented child migrants. One principal (Principal A) was adamant that all children, no matter their legal status, should have a right to attend school. Everyone in Principal A's school were asked to work towards this goal of access as central in the negotiations. The principal saw for example that in some cases it was necessary that, to protect them, undocumented child migrants had to be registered in the class lists under false identities. However, another principal (Principal B) opposed such activity due to concern that it contravened legal guidance. Principal B argued that unless the rules state otherwise, children who lack documentation to stay in Sweden should not be treated differently due to their vulnerable situation. Her main argument was that there should be no 'hiding' of students in the Malmö schools that contravened the law. Both the city attorney and Principal B, stating that the police possess the legal authority to request information about students, opposed informal or incorrect registers. The city attorney argued that it was problematic if the municipality engaged in any lack of transparency towards national authorities. Under Swedish legislation the police have a right to ask for these papers, despite undesirable consequences for the persons concerned, it was 
stated. Her argumentation was instilled by what Peter Skilling (2014) describes as a narrative of constant crisis, which affirms migration as a security problem.

In response, the activists talked about the importance of school for the everyday lives of unaccompanied refugee children. The Asylum Group-representatives also recounted that youth they were in contact with were afraid of accessing school, if safety could not be guaranteed. The meeting included a discussion over the possibility to make an analogous application of secrecy law's provisions concerning children with protected identity (for example, children who have been separated from an abusive parent). According to the city attorney, this was not possible because undocumented children were not expressively categorised in the Swedish Secrecy Legislation. Equality before the law, fundamental to human rights, was about just that: To not make a difference between categories of children, if the state through legislation explicitly had intended this.

To summarise, in the interviews and during the meeting ambivalence can be identified as regards whether to safeguard school for undocumented child migrants and if this should be done openly or not, which is strongly determined by whether actors refer to a legal or experiential discourse. Although there is a pronounced international framework for the right to education, scope for arbitrariness evidently is broad in relation to children who are undocumented. Combined with national legislation and initiatives such as REVA, regulations can be used either to include or to exclude children in irregularity. The negotiations and interview answers confirm that rights protection of children appears in different ways in international agreements, national and local guidelines. Central to the context of our respondents were different approaches to the implications of the international human right to education, and the absent question of why undocumented children residing in Malmö should have rights. This way the question of an underlying taken-for-granted approach to irregular migrants as 'someone who shouldn't be here' came in the back seat, something that previous research has shown to be an obstacle to actual change (Sinha and Gasper 2010).

Furthermore, perceptions of what human rights suggest in relation to undocumented children's education varied widely. The question of school for undocumented could, but was not, turned into what Manisha Sinha and Des Gasper (2010) in a different context describe as 'a symbol of a larger struggle against those negative values and so promote and obtain more support from civil society movements concerned with a range of related issues' (p. 303). For some of the involved actors, rights were about access; for others they implied equality before the law, in the sense that there should be no distinction in how children who are undocumented are treated compared to other children's situation. Still others had an understanding of human rights in local contexts as something closely linked to the state's exercise of force, which must be predictable and consistent.

The discussion about why undocumented children should have human rights was to a large extent overshadowed by negotiations around practical barriers for accessing rights, technical legal questions and discussions about different authorities' responsibilities and roles. There was significant tension over what different actors perceived as the correct policy to safeguard school for undocumented migrant children. In addition, these actors expressed competing interpretations over how to secure 
impartiality and equality before the law, as well as what set of legal guidelines should be followed.

The children's own perspectives, agency, was given expression in the category of removing barriers for school and within human rights as equal treatment. From the interviews it was noticeable that the children themselves claimed to be treated as everyone else. The fact that they despite the position as irregular in Sweden attended school was an enactment of rights. While aware of their subordinate position, and constantly afraid of being detected and arrested, they still claimed access. The complicated struggles taking place in Malmö, by the children as well as interviewees' and in the meeting in May 2012, were symptomatic of a much wider public debate within not only the city of Malmö, but across Sweden, that centred on the human rights of undocumented persons in general and the different measures taken to increase deportations. In the local context of Malmö complicated interactions came about that may be understood as processes of inventions of rights, possible conclusions from these processes are discussed in the following section.

\section{The importance of the everyday in human rights practice}

We have explored everyday struggle and the intersection between multiple sites of regulation coming together at the local level of the school policy in the city of Malmö. Initially it was stated that education is a basic human right that should apply to each and everyone, no matter their legal status. This is also imperative among the actors, international, national and local, who advocate that the barriers to school for children in irregularity would be eliminated. In the interviews and the meeting involving one of the authors, negotiations around children living clandestinely and their access to education was however also given expression in other ways. First, the question was whether there are legitimate reasons for special arrangements to guarantee undocumented children's access to school. Should they be treated differently to safeguard their access to an education? Second, it was discussed how policy should be interpreted from a legal perspective, i.e. to frame and interpret the will of the legislator was an important part of the negotiations. Key here was impartiality through treating equality before the law as a fundamental human rights-principle. If the legislator had not explicitly pointed to a specific group in legislation, then they should be treated as anyone else. Third, the meeting and interviews uncovered practical dilemmas in school arising from constant threats of deportation related to the overall consistency and coherence in enforcement of state power. One question related to this was how undocumented children simultaneously can be registered and kept outside of registration. The perspectives of youth themselves may be linked to both the question of equality and access. The latter in the sense that for children in an irregular situation, school is something that has shown to be of great importance for their everyday well-being (Lundberg and Ascher 2013). Their experiences, as undocumented, provided the basis for principal A's clear and explicit position that the right to schooling is not negotiable, and in any event shall be provided. Zeki Sarigil (2009) argues that paying more attention to agency would significantly improve the historical account of institutional or policy change. As regards equality, it appeared from the interviewees who had been in contact with several youth, that they sense the subordination through which deportability is materialised.

What may be described as a process of cosmopolitisation is taking place in the city of Malmö, where measures that extend beyond the Swedish state's human rights 
commitments are taken to safeguard the right to education for every child residing in the city. In these negotiations there are indications that human rights can trump the forces of criminalization of migration and de facto may constitute an arena of cosmopolitanism, to borrow Adami's (2012) concept implying that the universal may be understood through the particular by acknowledging the tensions that may arise.

Furthermore the situation in Malmö is an expression of social transformation in a broader sense linked to migration, namely how human rights come about for those who are deprived of legal residence in a European welfare state. The right to education on a city level of governance, in the city of Malmö, is an empirical example of a changing social space where human rights for undocumented persons are (de)contested. If we return to the tensions between the various regulatory levels an on-going struggle between the city of Malmö trying to provide for its' inhabitants' needs of services, and the nation state's interest in upholding migration control emerges. Rights-protection of children appears in different ways in international agreements, national and local guidelines. The tensions that arise between these levels are an expression of social transformation with implications for how we understand the relationship between marginalised groups and regulatory frameworks.

On one level, to include undocumented children in a city's welfare system, by for example granting them access to school, is not an act of kindness, or of technically applying national legislations, but an expression - or performance - of a society's existence. In his speech in the press conference mentioned to above the Swedish prime minister's reference to Sweden as 'open' is an example of such enactment. To a limited extent, this understanding pervades the notion of 'Soft Power' (or even 'Smart Power') in which States compete not via military might but a more subtle battle over 'hearts and minds', fought as much via cultural products as the smooth-tongued words of diplomats. Yet, at a more basic level, the inclusion of undocumented migrants in school demarcates the border of a society - stating the limits to its citizenship by recognising the 'other', and making itself visible to that outside itself. This way a process of cosmopolitanism can begin to germinate.

Put another way, the denial to be allowed to include would represent a severe constraint on a society's expression of its own existence and identity. At the societal level, to include persons in an undocumented situation in social welfare systems is to receive recognition as a society equipped to provide social goods (i.e. security, education). This is both for status and for self-acknowledgement as a society. Not only is the inclusion a badge that a society has 'made it' - has reached a certain level of development - but it should also be understood as important to how the society itself is maintained. Cosmopolitanism provided through the space of human rights can both perform and extend its own being, to encompass a wider body of humanity, but also make its existence materially felt through the lives of individuals.

\section{Conclusion}

In the governance of human rights, the local level has previously been an understudied field yet this ignores its importance given the extent to which human rights relies on its practice. We have in our article argued that the local level remains an important site for the negotiation processes through which human rights achieves meaning, as demonstrated in the case of access to education for undocumented migrants in the 
Swedish city of Malmö. There, an on-going struggle is taking place between the city of Malmö trying to provide for its' inhabitants' service-needs, and the nation state's interest in upholding migration control. The tensions that arise are an expression of social transformation with implications for how we understand the relationship between marginalised groups and regulatory frameworks.

The presence of undocumented children and education is complicated because education is perceived as a necessity for engaging within society, as well as an effective tool for social mobility. Access to education is a central benchmark for development indicators, and one of the central 'goods' requiring the existence of social organisation. Failure to provide access to education is, likewise, a frequently used measure of social collapse and state failure. It is for this reason that education serves as a key means by which societies interact, whether conducted through short-term exchanges of students, teaching personnel, or more long-term engagements such as where governments fund education premises outside of their own legal borders. Education is an expression of society - a raison d'etre, and a means to expand its domain.

There are multiple rationales given to justify and support the provision of education to non-citizens, including: promoting particular policies and worldviews abroad; encouraging foreign economic and political development; attracting highly-skilled labour and, socialising the future elites of foreign countries as amicable towards one's own state. It is also a basic human right for children and young persons to be able to attend school (regardless of their legal status). The undocumented migrant physically present but socially and legally absent in a society represents an emptiness in which society fails to perform itself within part of the territory that is the legally-defined basis of its existence.

To live under the threat of deportation or detention obviously affects everyday life, whether one is within the asylum process or lives as unauthorised. States have historically argued that control of foreigners is inevitably necessary to maintain an orderly life for its population. This in turn has led to a situation where the development of control systems, or the making of inequality under the law on the basis of that person's legal status, has become something completely 'unproblematic'. Yet, as we see in the case, the rights of undocumented child migrants are far from clear in policy. Practices of rights, and policy-development in the field of rights, rely much upon a negotiation process that takes place not exclusively at the global or national level, but that involves a series of complex interactions amongst multiple actors at the local level.

\section{References:}

Adami, R., 2012. Reconciling Universality and Particularity through a Cosmopolitan Outlook on Human Rights. Cosmopolitan Civil Societies: An Interdisciplinary Journal 4.2: 22-37.

Arendt, H., 1951. The Origins of Totalitarianism, Prag: Schocken Books.

Benhabib, S., 2007. Just Membership in a Global Community. Macalester Civic Forum. Vol. 1: Iss. 1, Article 11 available at: http://digitalcommons.macalester.edu/maccivicf/vol1/iss1/11.

Betts, A., Towards a 'soft law'framework for the protection of vulnerable irregular migrants. International Journal of Refugee Law 22.2 (2010): 209-236. 
Bhabha, J., 2009. Arendt's children: Do today's migrant children have a right to have rights? Human Rights Quarterly, 31(2), 410-451. doi:10.1353/hrq.0.0072

Carter, P., 2012. Policy as palimpsest. Policy \& Politics, 40(3), 423-443.

Chang, G., 2000. Disposable domestics: Immigrant women workers in the global economy. Cambridge, MA: South End Press.

Chataway, T., 2010. Cosmopolitical citizenship: Seeing the World through the eyes of others. Griffith L. Rev., 19, 375.

Committee on Economic, Social and Cultural Rights (2008); Comment on the Swedish government's report to the Committee, p 27). E/C.12/SWE/CO/5 1 December 2008.

CRC-committee (1999). Committee on the rights of the child, Twentieth session. Considerations of reports submitted by states parties under article 44 of the convention. Concluding observations: SWEDEN. CRC/C/15/Add.101. 10 May 1999.

Crépeau, F., Nakache, D., and Atak, I., 2007. International migration: Security concerns and human rights standards. Transcultural Psychiatry, 44(3), 311-337.

Dauvergne, C., 2008, Making People Illegal. What Globalization Means for Migration and Law. Cambridge: Cambridge University Press.

Dembour, M.B., 2010. What are human rights? Four schools of thought. Human Rights Quarterly 32.1: 1-20.

Donnelly, J., 2013. Universal human rights in theory and practice. Cornell University Press.

Geiger, Martin, and Antoine Pécoud, eds. The politics of international migration management. Basingstoke: Palgrave Macmillan, 2010.

Habel, Y. 2012. Neutralitetsbegär. Bang 2: 20-23

Hale, C. R. (2001). What is activist research. Social Science Research Council 2.1-2: 13-15.

Hill, D. W. (2010). Estimating the effects of human rights treaties on state behavior. Journal of Politics, 72(4), 1161-1174.

Hadiprayitno, I., 2014. A Socio-Legal Perspective to Human Rights Negotiations. Available at SSRN 2467156 (2014).

Huysmans, J., and Guillaume, X., 2013. Citizenship and Securitizing. Citizenship and Security: The Constitution of Political Being, 18.

Haraway, D. (1988). Situated knowledges: The science question in feminism and the privilege of partial perspective. Feminist studies, 575-599.

Ingram, J. D. 2008. What is a 'Right to Have Rights? Three Images of the Politics of Human Rights. American Political Science Review 102(4): 401-16.

Interview with Jammeh, S., K. in Sverige Radio P1, 6 $6^{\text {th }}$ April 2013, authors' translation.

Isin, E. F., Nyers, P., \& Turner, B. S. (Eds.), 2008. Citizenship between past and future. London: Routledge. Jernberg, Å., Karlsson, N. and Martinsson, T., 2013. Polisens jakt på papperslösa är omänskliga. Aftonbladet February 20.

Kesby, A., 2012. The Right to Have Rights: Citizenship, Humanity, and International Law. Oxford University Press.

Krause, M. 2008. Undocumented Migrants An Arendtian Perspective. European journal of political theory, $7(3), 331-348$. 
Laws. D. and Forester, J., 2007. Learning in practice: Public policy mediation, Critical Policy Studies, 1:4, 342-370.

Longino, H. E. (2002). The fate of knowledge. Princeton University Press.

Lundberg, A. and Ascher, H., 2013. Papperslösa barns rätt till utbildning i Sverige, in Hartsmar, Nanny et al Medborgerlig bildning (preliminär titel), Studentlitteratur: Malmö 2013, p 167-195.

Macklin, A., 2007. Who is the citizen's other? Considering the heft of citizenship. Theoretical inquiries in law, 8(2), 333-366.

Malmsten, J., 2012. I transit -șêp. ensamkommande barn berättarFoU-rapport 2012:1. ISBN 978-91-8663115-4 Stadskontoret

McNevin, A., 2006. Political belonging in a neoliberal era: the struggle of the Sans-Papiers. Citizenship studies, 10 (2), 135-151.

McNevin, A., 2011. Contesting citizenship: Irregular migrants and new frontiers of the political. Columbia University Press.

Merry S E., 2006. Human Rights and Gender Violence. Translating International Law into Local Justice. Chicago and London: The University of Chicago Press.

Mezzadra, S. and Nielsen, B., 2003. Ne' qui, ne' altrove-migration, detention, desertion: a dialogue. Borderlands e-journal [online]. 2 (1). Available from: http://www.borderlands.net.au/ [Accessed 13 December 2014].

Migration Board (2011) Annual Report. Available at: http://www.migrationsverket.se/download/18.478d06a31358f98884580001427/Årsredovisning+2011. pdf

MIG 2010:21, Migration Court of Appeal

Nicholas, P., \& Genova, D. (2002). Migrant "illegality" and deportability in everyday life. Annual review of anthropology, 419-447.

Nilsson, M., 2011. Polisen kan kräva uppgifter av skola. Sydsvenskan March 4.

Noll, G., 2010. Why human rights fail to protect undocumented migrants. European journal of migration and law 12: 241-272.

Nozick, R., 1974. Anarchy, state, and utopia. Vol. 5038. Basic books.

Nyers, P., 2003. Abject cosmopolitanism: the politics of protection in the anti-deportation movement. Third world quarterly, 24 (6), 1069-1093.

Nyers, P., 2008. No one is illegal between city and nation. In: E.F. Isin and G.M. Nielsen, eds. Acts ofcitizenship. London: Zed Books, 160-181.

Oberoi, P., 2009. The enemy at the gates and the enemy within: Migrants, social control and human rights. Project on Social Control and Human Rights.

Orsini, M., and Smith, M., 2010. Social movements, knowledge and public policy: the case of autism activism in Canada and the US. Critical policy studies, 4(1), 38-57.

Press act [Tryckfrihetsförordningen] Tryckfrihetsförordning (1949:105)

Reynaert, D., Bouveme-de Bie, M. \& Vandevelde, S., 2009. A review of children's rights literature since the adoption of the United Nations convention on the rights of the child. Childhood 16(4): 518-534.

Risse, T., 2013. Arguing about arguing: a comment. Critical policy studies 7.3 : 339-349. 
Risse, T., Ropp, S. C., \& Sikkink, K., 1999. The power of human rights: International norms and domestic change. Cambridge, UK: Cambridge University Press.

Ruiz-Casares, M., Rousseau, C., Derluyn, I., Watters, C., \& Crepeau, F. 2010. Right and access to healthcare for undocumented children: Addressing the gap between international conventions and disparate implementations in north america and europe. Social Science \& Medicine, 70(2), 329-336.

doi:10.1016/j.socscimed.2009.10.013

Rygiel, K. 2011. Bordering solidarities: migrant activism and the politics of movement and camps at Calais. Citizenship studies 15.01 (2011): 1-19.

Rygiel, K. 2011. Bordering solidarities: migrant activism and the politics of movement and camps at Calais. Citizenship studies 15.01: 1-19.

Sinha, M., \& Gasper, D., 2010. How can power discourses be changed? Contrasting the 'daughter deficit' policy of the Delhi government with Gandhi and King's transformational reframing. Critical Policy Studies, 3(3-4), 290-308.

Sinha, M., and Gasper, D.R. 2010. How can power discourses be changed? Contrasting the 'daughter deficit' policy of the Delhi government with Gandhi and King's transformational reframing (No. 493). Retrieved from http://hdl.handle.net/1765/19672

Socialstyrelsen, 2010. Social rapport [Social Report]. Available at: http://fra.europa.eu/sites/default/files/fra uploads/1771-FRA-2011-fundamental-rights-for-irregularmigrants-healthcare EN.pdf

Squire, V. and Darling, J., 2013 The "Minor" Politics of Rightful Presence: Justice and Relationality in City of Sanctuary. International Political Sociology, 191.

Strange, M., and Lundberg, A., 2014. Education as Hospitality. Peace Review, 26(2), 201-208.

Sylvan, C. and Magnusson E. 2011. Skåne har stått modell för hela landet. Papperslösa făr rätt till vård och skola. Trelleborgs Allehanda 4 mars.

Swedish Government 2012/13: 58 Education for children who are staying in the country without authorization [Utbildning för barn som vistas i landet utan tillstånd].

The City office of Malmö [Malmö stadskontor], 2013. Report, available here: http://malmo.se/download/18.a81ab142d709775413c9/1386766811869/Folkmängd_Malmö 2012.pdf \#search='andel+invandrare+i+malm $\tilde{A}$

UN (1951 and 1967) Convention relating to the Status of Refugees, July 28, 1951, 189 U.N.T.S. 150; Protocol Relating to the Status of Refugees, Jan. 31, 1967, 606 U.N.T.S. 267; 19 U.S.T. 6223

UN (1989) CRC, 1577 UNTS 3, 20 Nov. 1989 (entry into force: 2 Sep. 1990)

Vandenhole, W., de Wiart E., Verhoeven M. et al. 2011. Undocumented children and the right to education: illusory right or empowering lever?. International Journal of Children's Rights [serial online]. December;19(4):613-639.

White, A., Ní Laoire C., Tyrrell N., and Carpena-Méndez F., 2011. Children's Roles in Transnational Migration. Journal of Ethnic and Migration Studies, 37:8, 1159-1170 available at: http://dx.doi.org/10.1080/1369183X.2011.590635.

\footnotetext{
${ }^{\text {i }}$ Statistics September 30 ${ }^{\text {th }}$ 2012. Phone interview with Police department in Malmö, Sweden.
} 
